\title{
A CRITICAL REVIEW OF LEGAL FRAMEWORK AS A FACTOR OF COOPS DEVELOPMENT - CASE OF SERBIA
}

\author{
Goran Petković1, Biljana Chroneos Krasavac ${ }^{2}$, Vlado Kovačevićc ${ }^{3}$
}

\begin{abstract}
Contemporary cooperative movement must rest on the original cooperative principles that were confirmed and modernized by the Congress of International Co-Operative Alliance held in Manchester in 1995. Development of coops legislative framework in Serbia has a long history and presently the matter of cooperatives is governed by the federal Law on Cooperatives adopted in 1996. The text analyzes the extent to which a legislative framework can be an incentive for and/or impediment to cooperatives' operation in Serbia, and what sort of results can be expected from a modernized and improved legal framework. Interview of key players in the coop sector was one of the research methods. Other methods include historical, comparative analysis and case study. The paper includes four parts: a) historical and legal background of development of coops in Serbia; b) legislative framework; c) successful case study and d) framework for further development. The paper also analyses cooperatives within the environment of social enterprises and evaluates their role in the social inclusion process.
\end{abstract}

Keywords: coops, legal framework, ownership, agricultural household, individual producers

JEL: P32, K39, Q13

\section{Historical and Legal Background of the Cooperatives Development in Serbia}

In the course of World War Two, due to the economic crisis and war devastations most cooperatives and cooperative associations in Serbia (and in ex-Yugoslavia) ceased to

1 Goran Petković, Ph.D., Full Professor, University of Belgrade, Faculty of Economics, Belgrade, Kamenička Street no. 6, 11000 Belgrade, Serbia, Phone: +381-11-30-21-130, E-mail: pego@eunet.rs

2 Biljana Chroneos Krasavac, Ph.D., Assistant Professor, University of Belgrade, Faculty of Economics, Belgrade, Kamenička Street no. 6, 11000 Belgrade, Serbia, Phone: +381-1130-21-186, E-mail: biljanak@ekof.bg.ac.rs

3 Vlado Kovačević, Ph.D, Minister advisor, The Ministry of agriculture and environmental protection, Government of the Republic of Serbia, 11000 Belgrade, Nemanjina Street no. 22-26, Phone: +381-64-65-81-519, E-mail: vlado.kovacevic@minpolj.gov.rs

EP 2016 (63) 1 (261-278) 
operate. A phase of recovery of the cooperative movement in the post-war period then followed. Four years after, in 1949, a new law - Basic Law on Farm Cooperatives was passed (Official Gazette of the Federal Republic of Yugoslavia, June 6, 1949), which defined the cooperative as an economic organization where working age peasantry get together in order to improve the agricultural production, raise their living standard and build socialism in the country.

Apart from providing the members with intermediates for selling their produce, the cooperatives were also playing an educational role. They organized competitions of farmers and similar activities which contributed to the development of agriculture and the village. Since the state authorities believed that agriculture and village promotion would be most efficiently accomplished through the cooperatives, they were given the monopoly of its own kind over the purchase of agricultural commodities from peasants, purchase of agricultural machinery, etc. Privileged position held by the cooperatives in relation to other entities in agriculture, and economic and social gains and interests that cooperative members accomplished through their respective cooperatives, played a strong role in massifying their membership and in strengthening the economic position of the cooperatives.

These processes were taking place in the circumstances of limited right to private ownership (maximum 10 ha of land holding per household, impossibility to purchase machinery, etc.). Therefore, concentration of cooperative property represented a way for cooperative members to also introduce new technologies, apply up-to-date agrotechnical measures and introduce new knowledge to their own holdings.

The 1953 Constitutional law and further economic reforms in 1965 weakened substantially the position of the co-ops. Their property became "nobody's" and "everybody's" socially-owned property, while their monopoly diminished enabling farmers to work directly with other economic operators. The labour economic principle publicly stated by the reform has thus left aside the cooperatives with their enormous labour force and machinery. It was one of the most unfavorable periods of the cooperative system in Serbia. The property of former cooperatives is even today subject of settlement in numerous courts.

The expansion of cooperative movement was halted by the changes that the Law on Associated Labour (Official Gazette of the SFRY, Issue No 53/764, December3, 1976) brought along (between 1972 and 1976), when cooperatives got drowned in stateowned, and/or "socially-owned" enterprises. Under the name of basic organizations of contract farmers, cooperatives became parts of agricultural enterprises and agroindustrial complexes, thus losing their legal and economic subjectivity. Consequently, in the period from the 70s until 90s there were no farm cooperatives as independent legal entities. At the time when cooperatives were transformed into Basic Organizations of Contract Farmers, they held in addition to about 200,000 ha of land, 10 slaughter houses, 6 dairy plants, 19 flour mills, 2 flour processing and pasta factories, 8 fruit vegetables and grape processing factories, 11 fodder mixing plants, 4 hemp spinning 
mills, 17 building plants, 27 installations for trading in industrial commodities, etc. All ownership rights to the above listed property (as well as to non-mentioned working assets) were transferred to the social sector by the drowning of the cooperatives in socially-owned agricultural enterprises and agro-industrial complexes.

Amendments of the 1988 SFRY Constitution reintroduced the cooperative property as an equal form of ownership, while a new Law on Cooperatives was passed in 1990 (Official Gazette of the Federal Republic of Yugoslavia, No. 67/93, 46/95 and 101/05). The intention to return the cooperatives' property back to co-ops failed due to inefficient legal procedures.

These issues were additionally complicated by the law adopted in 1992, which in the instructions for the mode and procedure for establishing and recording the agricultural land in state and social ownership neither mentions the cooperative property nor land in cooperative ownership.Although the new Law on Cooperatives of 1996 attempted again to force the return of property to co-ops, it never happened and the damage appeared to be unrecoverable.

Currentlyvalid Constitution from 2006 (National Assembly of the Republic of Serbia, 2006, Constitution of the Republic of Serbia, RS Official Gazette, No. 98/2006) recognizes three forms of ownership, public (state), private and cooperative. Takinginto account the fact that social ownership exists no longer, a question arises as to why the courts are further doing injustice to the cooperative movement and why are booking the disputable property as state-owned? Or, why are they protracting disputes infinitely?

In parallel with the transformation of Basic Organizations Of Contract Farmers into cooperatives, since early $90 \mathrm{~s}$ has started the forming of new cooperatives by farmers who see in the cooperative organization a possibility for accomplishment of their economic interests. Joint characteristics of the transformed and newly-formed cooperatives involve (save for the fact that they operate in conformity with identical legal provisions) the lack of capital, lack of fixed and working assets, poor personnel structure, etc.

Contemporary cooperative movement must rest on the original cooperative principles that were confirmed and modernized by the Congress of International Co-Operative Alliance held in Manchester in 1995(Statementon Co-operative Identity, General Assembly of the ICA, Manchester, 1995). Farmers' cooperatives are the only right and correct mode of organizing the farmers in organizations without which the existence of the village as such is in question. Preservation of the cooperative movement and improvement of its activity and operation necessarily requires stopping the fall in agricultural production, which is achievable by a more efficient implementation of economic and agrarian policy measures. Such measures have to be created by representatives of the cooperatives as the keyorganizational segment of farmers in Serbia. Adequate implementation of the agrarian policy implies that the incentives provided by the government for agricultural development reach true beneficiaries - primary farmers - cooperative members. Also, small-sized farmers have to be better protected by adequate measures, such as 
cooperative internalization of critical transactions, both in the area of supply and the area of sale of their products (Valentinov, 2007).

The text below analyzes the extent to which a legislative framework can be an incentive for and/or impediment to cooperatives' operation in Serbia, and what sort of results can be expected from a modernized and improved legal framework.

\section{Methodology and data sources}

This paper continues the research regarding the historical development, role and the impact of the coops' movement on the development of the agriculture and rural economy in Serbia, from the emergence of the first coop until now (Chroneos Krasavac, Petkovic, 2015). Several influential factors were revealed through the research process, among which, the legal framework appeared to be the most important. The paper is based on different data sources. The first group includes three types of documents, i.e. academic papers, all legal acts covering this field in Serbia from the beginning of coop movement and finally, official documents and reports of EU and the other international organizations. The other group of data sources is the empirical data.

The empirical data were collected through structural interviews of key stakeholders involved in cooperative business in Serbia. There were six sessions involving three researchers in discussion process based on the list of questions prepared in advance, targeted to the main coop development issues. The content of the answers and responses collected through this process were analyzed in order to extract the key factors that shaped the development process of the coops in Serbia. These findings were subject of the comparative analysis with the legal frameworks of more advanced coop environments and economies, particularly EU ones. Derived conclusions were, once again, verified on successful case study of private company whose business model is based on the basic principles of cooperatives.

\section{Legal framework as a factor of coops developmentin Serbia}

Presently, the matter of cooperatives is governed by the federal Law on Cooperatives adopted in 1996 ("FRY Official Gazette", numbers 41/96, 12/98), and the Law on Cooperatives from 1990 ("Official Gazette of the Republic of Serbia", numbers 57/89, 67/93, 46/95 and 101/05). The Government of the Republic of Serbia, during several of its recent terms of office, has been engaged in drafting a new Law on Cooperatives. Morethan 8 different versions have been prepared, but a new Law has not been adopted yet.

Some of the shortcomings regarding the legal framework as a factor of coops development in Serbia are identified as such:

The first difficulty one encounters is the legal dualism because social relations in the field of cooperatives and cooperative movement are currently governed by two above mentioned laws, which have also been several times amended. In such a situation, 
certain legal norms overlap, causing non-uniform application, different interpretations and absolute incompliance with the contemporary socio-economic circumstances. Therefore, the need for adopting a new law is more than evident because the cooperatives and the cooperative movement in the Republic of Serbia are exposed to multiple difficulties.

The second shortcoming manifests in the obsoleteness and non-functionality of the legal solutions adopted in the circumstances of essentially different economic, social and political circumstances. It is also necessary to take into account the different legal and constitutional system of federative state order with a two-level legislative power. Also, there is a need for harmonizing the domestic regulations with the regulations and legal acts of the European Union (Common market organization directive (EU) 1308/2013 of the European Parliament) in the area of cooperatives and cooperative movement. The need for these changes also arises from the necessity to proceed to the reform of domestic cooperatives and of the cooperative movement. The goal is, following the example of the developed countries, to rehabilitate the significance of cooperatives and of the cooperative movement, and create the conditions for them to become an important and dynamic factor of economic development. Expectation is to enable, through cooperatives, settlement of the accumulated economic and social problems, which is relevant in the current stage of implementation of the transition of the Republic of Serbia's socio-economic and legal system. This is the reason why the countries members of the International Co-Operative Alliance (ICA) have been given an instruction and/or recommendation to proceed to the reforms of the cooperativerelated legislation. Intention is to create an ambiance for enhancing the market and entrepreneurial function in the operation of cooperatives. This can be achieved by full harmonization of domestic legislation with applicable European standards rather than by partial amendments of the existing laws.

Unresolved property rights relations represent the third and the most pronounced shortcoming which is a key barrier to the development of the cooperative movement. Legal status of cooperatives' and cooperative associations' property has been recorded as socially-owned which disenables the cooperatives, inter alia, to use this property as an instrument of security for a bank loan repayment. Also, unsettled property rights relations lead to problems in the process of privatization that had to take place. The issue of disposing of cooperative property has partly blocked further development of cooperatives. Recorded court disputes conducted for restitution of the cooperative property show the number of 186 requests on the basis of which are claimed about 39,000 ha of arable land, 800 ha of ponds and over $70,000 \mathrm{~m} 2$ of storage facilities, business premises and housing space. Until 2011, in the court proceedings were decided less than $4 \%$ of filed requests, on the grounds of which was returned about 1,500 ha of land and about $3,000 \mathrm{~m}^{2}$ of facilities.

The fourth problem is the absence of a stimulating effect of legal regulations on the management transformation of cooperatives and on the strengthening of its market functions, as a must in contemporary circumstances. Further, a need arises for legal EP 2016 (63) 1 (261-278) 
recognition and a higher level of regulation of the cooperative sector's autonomy within the category of economic operators. That will create a legal basis for enactment of appropriate incentives and facilities in separate laws.

The fifth problem is the inefficiency of the legal institutes of applicable laws, principally in terms of the exercise of public authorizations entrusted to cooperative unions. Cooperative unions have by these authorizations got the right to pass general rules that regulate application of the cooperative principles and other issues relevant for operation of the cooperatives linked by those unions. Further, unions also adopt the rules which set forth the conditions that have to be observed by cooperative unions and auditors who do the cooperative audit, the contents of audit reports, and other issues relevant for cooperative audit. These legal acts represent the by-laws for enforcement of the laws that govern operation of the cooperative. As cooperative unions are authorized for passing the mentioned acts, and for their enforcement as well, without having been envisaged any efficient supervision over their operation by a competent government authority, a series of irregularities and deformations occurred in the operation of cooperatives and cooperative unions, particularly in terms of conduct of the cooperative audit. A need arises, therefore, for legal regulation of the cooperative audit, which would imply definition of the conditions necessary for getting licensed for performing cooperative audit, for issuance and revocation of the license, contents and mode of keeping a directory of cooperative auditors, mode of performing the cooperative audit, and supervision over the work of cooperative auditors.

The sixth problem manifests in the fact that the Law does not recognize and, accordingly, does not regulate special cooperative forms. Such are, for example, social cooperatives, whose mission is to settle some social issues. However, the unregulated status of these cooperatives makes more difficult their origin and development (Šunderić, 2008). In connection with this concrete issue there have been numerous dilemmas with regard to a cooperative forming and other special forms of cooperatives, such as "women's cooperatives", with a special focus on the creation of an economic ambiance in the countryside in which women would be willing to stay and have employment ensured ( Mijatović et al., 2012). Improvement of the law in this area would, at the same time, create a favourable climate for getting recognition for the last established - the seventh principle of cooperative movement which relates to the care for community (Serbian Cooperative Union, 2012).

From all of the above listed issues, also arises the fact that the bulk of agricultural and other producers ("creators of new values") in Republic of Serbia are neither sufficiently organized nor protected, nowadays. This is the reason for the need of having a better organization, expansion and promotion of cooperatives forms in doing business. Moreover, a problem is also that a large portion of expert circles and the general public unjustly regard the cooperative as an obsolete and anachronous form of operation without further perspective (Gulan, 2013).

The lack of a contemporary legal framework is in most cases an impediment to 
a successful cooperative movement. Below in the text,we are presenting the case of successful private organization in the area of primary agricultural production. Substantial part of their success stems from mutually beneficial cooperation with the existing coops in the region. The purpose of those private organizations is to fill the gap originated by distortion of the coop structure, presented in the previous text. There are different answers in different national economies, but also in different epochs of the development to the dilemma: "cooperative or private initiative". However, the international experiences from developed and well-structured agricultural' countries, demonstrate the complementarity of private and coop organizations regarding the specialization in performing different tasks in supply chain of primary agricultural products. Having that in mind, the presentation of the case study of private organization "Agrogrnja" is followed in the text by the latestinitiativein the development ofthe cooperatives'legal framework (Draft Law on Cooperatives, 2015).

\section{Business Case of the Successful Private Organization "Agrogrnja"}

Private company "Agrogrnja" d.o.o. was incorporated in 1996 inPivnice, a place in the Province of Vojvodina, Republic of Serbia. The Company developed from a small family-run production of fodder, and has been registering a permanent growth which is accelerating. Thus, the 2009 turnover was EUR 7.9 million with 32 employees. In 2013, the turnover more than doubled and was at the level of EUR 18.8 million with 74 employees.

Basic activity of the company includes organization of primary agricultural production, purchase and sale of agricultural commodities, as well as service providing (drying, etc.) and exports and imports. The company is among the biggest in the segment of contracting and organizing primary agricultural production. It is organizing production on 6,000 ha, and purchase at 22 buying stations. The company is trading in commercial goods, primarily cereals (except rice) and oil plants. Among the key internal factors of the success of this company are also the professionalization of management and loyalty on the part of cooperative members.

Association represents one of the key factors of success of this type of companies. "Agrogrnja"d.o.o. is operating within the Global Union association which also includes the "Business Park" BačkiPetrovac, "Danube Agro Logistics" and other companies. Further, the company is a member of "VojvodinaAgrar" association. The head-office of this probably one of Vojvodina's most important agricultural associations is in Bečej. The association has 26 members with more than 25,000 contract farmers. All members are organizers of production, and a few of them also have their own production. "Agrogrnja", d.o.o. is one of the leading members of the association and is investing efforts and advocating further growth (the goal is 150,000 ha) and an even stronger integration of the members. As of recently, "Agrogrnja" d.o.o. has also become a member of the association of NonGMO producers of soya, "DonauSoja", having its head office in Vienna, and is the only member, among 130 other members, coming from Serbia. 
Professional management is also an important factor of success of the company. It is a medium-sized enterprise with modern organization and a defined mission and vision of development. Business processes are covered by ERP software. All buying points and all services in the enterprise are directly linked, and processes are automated. Organization is formalized and based on systematization and description of jobs. All operation functions are functioning, including HR and controlling. The company has a development strategy based on strategic analyses and monitoring of the world food markets through technical services of the company and also via specialized consulting firms. The development strategy also envisages development of a new loading capacity on the Danube, on the Beočin location, the goal being to optimize the logistics costs and raise the company performance. The location was purchased from the cement plant "La Farge" which is planning to develop its loading platform in the same place. This will be an important loading place, if compared with the already existing capacities in Bogojevo and Pančevo.

"Agrogrnja" d.o.o. is precise and specific in defining its position in the chain of supply of primary agricultural commodities. The chain consists of five levels and participants on each of them.

Level I producers of primary products - agricultural households;

Level II organizers of production of first order - cooperatives and enterprises with 1 buying station;

Level III organizers of production of higher order - enterprises and cooperatives with several buying stations;

Level IV a) processing industry (processors);

b) exporters;

Level V Multinational Trade Companies (MNC).

This chain of supply has several branches on each of the listed levels. For examples, processors are at the beginning of their chain of supply which further extends to food industry and marketing channels of food products. However, further elaboration of the channels is not necessary for understanding how the basic chain of supply functions. The key for efficient functioning of the chain of primary agricultural products supply in Vojvodina is almost the strict division of functions between the levels. There have been, and will also probably be in the future, the attempts by participants from different levels of this channel to take over the functions of other participants. Up to now, all such attempts have failed to a larger or smaller extent. Sunflower processors were trying to organize the primary production and purchase, but have desisted. The reason is a fragmented holding and the need to concentrate quantities of a large number of small producers on a broader space. Holdings in Europe are much larger and it is possible for a processor to organize the purchase within a circle of 200-400 km with its own logistics and with the logistics of large farmers. In the United States, processors even 
have in their ownership the companies-organizers of the production. However, arable surfaces are incomparably larger. In Serbia, for the time being, concentration of the production of small producers is done by the participants on the second and third level of the chain of supply (USAID, 2008).

Loyalty of contract farmers represents, perhaps, the most important factor of business success for organizers of agricultural production. Unlike loyalty strategies on the market of final goods and services, the goal in primary agricultural production is to ensure loyalty of primary producers-contract farmers. "Agrogrnja" d.o.o. has for such needs even introduced the loyalty cards serving for identification of contract farmers in several places - contact points. This "benefit club" of its own kind ensures for contract farmers the benefits at the points where they spend the major part of their earned money, raising in this way the value of their wage. The most important advantages for the club members include: a) rebates and more favourable purchase price of the machinery; b) discounts at the time of contracting insurance; c) more favourable terms and conditions with banks; d) discounts provided by tourist agencies; e) benefits when shopping in the local chain of supermarkets. Contract farmer acquires these benefits after three years of regular settlement of the contractual obligation vis-à-vis the enterprise. In this way, the organizer of agricultural production upon contractual bases partly performs the functions that cooperative members would otherwise expect from their respective cooperatives.

Stable relationships on the market and association are an important external factor of success. Purchase prices are relatively uniform. In Serbia, in Vojvodina in particular, labour division between the participants in the channel has stabilized and is functioning. Each sugar processing plant or oil factory easily provides for the inputs it needs from the buying agents at the same price. The prices are essentially dictated by the world market through MNC. It sounds paradoxical, but the price depends more on the world price than on the season on local crops. This explains the view that sporadic local protests of farmers are oriented to regulation of the government subsidies rather than to product market prices. However, this view cannot be fully accepted because the awareness of the need to put together and concentrate small producers has been rising. An argument can be heard that business association "VojvodinaAgrar" (the member of which is the CF Gospodjinci) is a highly valuable factor underlying the stable functioning of the chain of supply in whose scheme it is invisible. This association acts as a defender of producers' interests against large processors. It manages, for example, to achieve with the largest soya processor a share in the supply of about $40 \%$ and, accordingly, a much more equal treatment in negotiations. It seems that spontaneous market flows had regulated the imperfections of the market by concentrating both the supply and the demand before the inefficient state authorities managed to perceive the problem.

Republic authorities in charge of market regulation are poorly organized. The share of the Republic Directorate for Commodities Reserves is 5-10\% in the total turnover of the products under review. The government is (not) an essential active participant on the market. The problem is that government authorities are working without precise 
data: there are no exact data even about the sown surfaces, or about yield estimates, etc. Precise estimates of other countries, big producers (the United States, and the like) and information coming from the world commodity exchanges have a much stronger influence on the market. The Agricultural Produce Exchange of Novi Sad has marginal importance for the market of commercial goods. It is believed that "the best thing for all market participants is that the Government does not interfere", except with regard to elimination of the legal impediments that it has been creating through history.

\section{Comparison of various forms of organizations for primary agricultural production}

The analysis of our business caseshows great similarities between a cooperative and a private company in performing the same work. Key factors of success are identical for them: professionalization of management, loyalty of producers and joining together in business associations. The only essential difference between a cooperative and a private company lies in the nature of ownership and the speed of decision-making.

It is also suggested that clusters and associations of farmers are a better form of organization than cooperatives. Some of their advantages are as follows (Iliopoulos, 2013):

a) unification of all purchases within a cluster;

b) basic driver of all activities - interest;

c) management - according to economic strength, clear, efficient and unambiguous;

d) production is concentrated - even large producers have a need to join together and associations are a true form for that.

Nevertheless, it is likely that at least in the medium run private companies, cooperatives and farmers' associations will continue to perform their activities in parallel. In the cases where cooperatives will maintain the trust of their members and contract farmers, their functioning and even expansion will, perhaps, continue. In the cases where they will fail to build good quality relations, private business will develop as a more aggressive and a more resistant form of functioning. A question arises here concerning the national culture and the relationship between individualism and collectivism. According to original researches of national cultures, collectivism in the former Yugoslavia was far more accepted than in other European countries and the United States (Hofstede, 2001). This implies that slight inclination to cooperative farming can be expected. This further leads to an analysis of the attitude towards management and its professionalization. Further development of cooperatives requires more professional management, clear relations, but also less expectation from the organization to jump in to help. Cooperative members, much more oriented to collectivism, express solidarity more readily (Janićijević, 2008), although such attitude can sometimes endanger the cooperative as such.

The experience from the business case shows that in spite of the confusion which is present in legal regulations, it is possible to do business successfully as a primary 
agricultural producer both in private and in cooperative ownership. It goes without saying, however, that without the improvement of the legal framework survival of the cooperatives in Serbia will in the long run be called into question. It is possible to quote several reasons that may jeopardize further development of cooperatives. The process of concentration has a strong impact on primary agricultural production causing disappearance of small "players" from the stage. The cooperatives not having a favourable legal framework for the raising and placing of their assets, of for borrowing, are losing the race with the mentioned concentration processes in comparison with private enterprises. Further, the process of globalization has a destructive effect on ethnic links that sporadically used to be crucial in rural environment for association of cooperative members. Also, social entrepreneurship as such stands poor chances of survival in the market competition if the role of the state is not specifically defined (Zakić, Stojanović, 2012). The existing confusion in the regulations has adverse impact on the position of social entrepreneurship. All of the mentioned reasons, and the need for harmonizing the regulation with the European Union, necessarily require an urgent response. The Government has to remove, within the shortest period possible, the legal impediments to further development of cooperative farming in Serbia, which is elaborated in greater detail further in the text.

\section{Framework for future development}

Cooperatives are of enormous importance for the agricultural sector in Serbia mainly for the reason of small average surfaces of agricultural holdings (Republic Statistical Office, 2012) of 5.4 ha only, which are divided in more than three plots, on average. In most cases, it is neither possible to organize an efficient and profitable production nor apply modern agronomic practices and new technologies on small holdings. The result of small holdings also reflects on the exportation of agricultural commodities. Despite the fact that agricultural sector is one of the rare and few sectors in Serbia that is recording a positive foreign trade balance, its structure is inappropriate because exportation of raw agricultural products is dominant.

Although the process of agricultural holdings' consolidation is evident, the process is slow so that the only option for achieving economy of scale and increased profitability of agricultural holdings lies in association (pooling).

By forming pools, agricultural producers in Serbia have a possibility to increase their profitability through (1) purchase of intermediates at lower prices as larger quantities are purchased, (2) improvement of the sale of products through integration of larger quantities of products offered to the buyer and smaller transportation and sales costs, (3) smaller costs of the agricultural machinery and equipment, as well as the possibility to apply new technologies through collective utilization of the machinery and equipment, (4) a more convenient group certification for different market standards, (5) easier transfer of knowledge and new technologies through group trainings, (6) building of collective processing and warehousing capacities. 
The conditions necessary for improving the pooling in agriculture can be divided into two areas:

1. improvement of the legal framework relating to cooperatives, and

2. improvement of the general business ambiance relevant for cooperatives.

\section{Improvement of the Legal Framework Relating to Cooperatives}

A new draft Law on Cooperatives is under preparation in the Ministry of Economy. The task force preparing the said draft also involves the representatives of the Ministry of Agriculture and Environment Protection, The Business Registers Agency, Cooperative Union of Serbia, Cooperative Union of Vojvodina, and experts in this area coming from different institutions.

Public debate about the Draft Law ended at the close of September 2015. The basic characteristics agreed upon in the Draft Law thus far include:

- The Draft governs all types of co-ops so that agricultural, housing, consumer, artisan, social, student-youth, pupil, health and ecological, as well as other types of cooperatives dealing with production, sale of goods, rendering of services and other activities.

- A possibility of non-equal stakes of co-op members has been introduced, while the property of co-op members is maintained through the category of contributions and stakes. Both amendments can be viewed as highly important taking into account that the obligation of equal contributions of co-op members turned out to be inefficient in the Serbian and foreign practices. Enabling non-equal contributions makes possible a larger capitalization of the co-ops because in the hitherto practice a cooperative member with the least funds used to determine the "upper limit" of the contribution".

- The draft Law envisages an automatic transfer of the entire socially owned property to the cooperative property without additional evidence if the socially- and state-owned property has already been defined. The practice thus far has been to register all cooperative property as social with frequently different types of entry in the Cadastre. The mentioned provision enables the cooperatives that have already proven their property not to carry out the same long-lasting procedure from the beginning. It is noteworthy that this is an issue which is not uniform. Actually, there are various types of property related issues that are intended to be resolved maximally by the draft Law. The issue that remains open is whether to allow the sale and pledging by this type of property or whether the property, as in Slovenia, will be given for utilization without the right to pledge or sell the same. The draft Law envisages that in case of discontinuation of an "old cooperative" the property is to be allocated

4 The practice was to leave out a cooperative member who was not able to invest additionally in the cooperative. 
to the Cooperative Association the member of which was the discontinued cooperative. This is certainly not an optimal solution in view of the unclear procedures in the case of a cooperative's membership in several cooperative associations, which can potentially lead to court litigations and blocking of property. A recommendation would be to select simple procedures for the transfer of such cooperative property to the local government or the state with a clear obligation that priority at transferring such property must be given to cooperatives.

- A possibility for small cooperatives of up to 20 members not to have a managing board, while a legal possibility is being sought that the director of a small cooperative of up to 20 members may discharge this function without remuneration. Needless to say, these changes are positive and unburden the costs of small cooperatives.

The issues remaining open in the Draft Cooperative Law:

- A possibility of including a legal entity in the cooperative is a practice that could contribute to increased capital of cooperatives;

- Establishment of saving-credit cooperatives and saving-credit divisions in agricultural producers' cooperatives. Serbia has a tradition of saving-credit cooperatives longer than one century. Currently, this type of cooperative is not possible, and based on the view of both the NBS and Ministry of Finance was rejected the request of the Ministry of Agriculture to make possible this particular sort of cooperative;

- Enabling that all acquired property is recorded with cooperative members. The hitherto practice of "general property" creation in cooperatives has had a markedly negative impact on cooperatives' capitalization. Namely, as it was unknown who the owner was, the economic interest of cooperative members was not to keep (immobilize) their property in the cooperatives. This is one of the key provisions that will stimulate the cooperative members not to withdraw property from the cooperatives but to have it added to their respective stakes.

- In the case of bankruptcy of "new" cooperatives created exclusively with private capital, the practice in all successful cooperative systems, with the exception of France, has been the distribution of this property to co-op members based on their respective stakes.

If personal property created as a result of the stake and efforts of cooperative members is distributed to cooperative associations or is alienated in other ways, individual producers will opt for a different type of economic organization where everything that they produce will remain their ownership, rather than for establishment of a cooperative.

- The possibility for "new" cooperatives to get reregistered in a different form of company enables flexibility and in the case of fall in the number of cooperative 
members below the legal minimum allows the private sector in the cooperatives to freely select the form of organization. Erroneous is the thinking that the keeping of cooperative property in that form and various restrictions improve the cooperative sector, as already shown by the practice of EU cooperative systems, because in such restrictive systems a small number of cooperatives is formed and they, as a general rule, have small capital. Consequently, in lieu of contributing to the cooperative sector, the mentioned restrictions actually bring the cooperatives in subordinate position in terms of business against other forms of economic organization.

- A possibility of selling the cooperative stakes is desirous and makes the system flexible. An advantage of this solution is that in a situation where a cooperative member leaves the cooperative there is a possibility of selling the stake of such member. In this way, the cooperative is not burdened with the stake payment and, on the other side, this system is more just and more stimulating for establishment and operation of cooperatives in view of the fact that stakes can be worth substantially more than the value on books which, as a general rule, is paid out by the cooperative after the cease of the cooperative member's status.

- Introduction of a member - investor is being practiced in almost all developed cooperative systems, which ensures a larger capitalization of cooperatives. As a general rule, here is also introduced a various number of votes depending on the level of capital. According to experts' opinion, despite numerous positive aspects of these amendments, introduction of this modification in practice will be possible in the next amendments of the Law on Cooperatives.

- Cooperative auditing that did not function at optimal level in the previous period and was under the scope of competence of cooperatives' associations is planned to be shifted to the General Cooperative Union, if and when established, or that the Ministry of Economy assume this function and delegate it to relevant cooperative associations.

All of the above listed functions are characteristic for almost all developed cooperative systems in the world. It is paradoxical that the countries not having the law on cooperatives or having a several-page law have the most successful cooperative systems precisely thanks to freedom and a small number of restrictions imposed on the cooperatives. Essentially, of greatest relevance for the development of the co-op sector in Serbia is to have a simple, clear law that stipulates a simple cooperative forming procedure and operation, and the lowest possible costs for the cooperatives. Further, it is necessary to establish a clear property distribution system and thus avoid the presentday situation where property without its defined titular is heaping up in the cooperatives. By giving to cooperatives a business function that is not in subordinate position relative to other forms of economic organization, establishment of cooperatives and their capital increase will be spurred, taking into account that cooperative members do not currently have any economic interest in leaving the property in a cooperative the ownership of which is undefined. 
The Common Market Organization Directive envisages the obligation of setting up a special form of association of agricultural producers-manufacturing organizations. Manufacturing organizations are the cooperatives of agricultural producers dealing with one line of production and falling in the so-called light market measures. The purpose of manufacturing organizations is to enable the communication of line institutions with the precisely determined group of producers. For example, if the agrarian policy in the area of milk is concerned communication is conducted with a milk producing organization. In the case of classical agricultural cooperatives, the agrarian policy creators do not know if they communicate with the producers from the appropriate area. One farmer can be a member of different manufacturing organizations, but of only one manufacturing organization within the line of production (this ensures that a farmer does not have "several votes" in the framework of one type of manufacturing organization). Further, there is a special system of EU subsidies for the manufacturing organizations, which lasts five years from the moment of a manufacturing organization's establishment. The Ministry of Agriculture is planning to adopt the CMO and to establish thereafter, by end of 2016, the licensing of manufacturing organizations within the Agrarian Payment Administration.

\section{Improvement of General Business Ambiance Relevant for Co-ops}

Cooperative system is not an isolated island. Therefore, apart from a good quality legal framework it is also necessary to improve the general business ambiance that is relevant for cooperatives. First and foremost, a stimulating tax system has to be put in place. The present-day VAT system treats the co-op members as third parties vis-à-vis the co-op, while the issue of double taxation and other issues are also important. Other matters emerging in practice, such as the impossibility for co-ops to perform the overhaul, impossibility for co-op members to return through co-ops the provided ear tags for cattle, and many other issues are significant. Once resolved, they will contribute to raising additional interest in doing business in the framework of cooperatives.

Provision of information to and education of farmers relating to their pooling in cooperatives are of great importance. In this regard, the Ministry of Agriculture envisages specifically within the reform of the Advisory Technical Service the work of advice providers and assistance rendering in a co-op establishment and functioning.

Changes in the subsidy provision policy and acceptance of EU principles according to which only the cooperatives realizing more than $80 \%$ of turnover with goods and services are eligible for subsidies would be significant for the support to "true cooperatives".

The new legal framework will bring contemporary legal solutions adapted to modern market, economic, financial, legal, constitutional and socio-political order and system. New regulations will establish the mechanism that will attract financial assets to cooperatives and also resolve the issue of accumulated income and sales. Legal regulations will stimulate management transformation of the cooperatives as market oriented economic entities. 


\section{Conclusions}

The example of analyzed entity in primary agricultural production suggests that best motivation is achievable by combining the cooperative and commercial principles. Solidarity and responsibility towards local community strongly raise the performance of private companies in contacts with farmers in the same way in which management professionalization and interest-based joining together in economic associations significantly raises the performance of cooperatives (Deller et al., 2009).

The first prerequisite for further improvement of the cooperative sector in Serbia is the establishment of a legal framework that governs clearly the property relations, enables settlement of "old" co-op property and improves and simplifies the cooperatives' operation, all with the intention to be accepted the principles of cooperative operation in EU member states having a successful cooperative practice. In this way, the number of cooperatives will increase, their capital will go up, and the economic aspect of the co-ops' operation will generally improve.

Of relevance is also the establishment of a legal basis required for setting-up the manufacturing organizations, which will increase the farmers' influence on the agrarian policy, make it possible for state authorities to create general purchase contracts jointly with producers, allow the use of EU subsidies (Ševarlić, 2012).

As to the measures intended to improve the general business ambiance, one particularly stands out in terms of importance: establishment of a stimulating tax policy, provision of information to farmers and their education, subsidies linked with the condition that a certain turnover of a co-op members be carried out through the co-op. In this way, fictitious cooperatives will be excluded from the subsidization system.

\section{References}

1. Chroneos Krasavac, B., Petković, G., (2015): Cooperatives In Serbia - Evolution And Current Issues, Economics of Agriculture, Vol. 62, No. 3 Belgrade, pp.723-736.

2. Common market organization directive (EU) 1308/2013 of the European Parliament and of the Council of 17 December 2013 establishing a common organization of the markets in agricultural products.

3. Deller, S., Hoyt, A., Hueth, B., Sundaram-Stukel, R. (2009): Research on the Economic Impact of Cooperatives, University of Wisconsin Center for Cooperatives, Madison.

4. General Assembly of the International Co-Operative Alliance (ICA), (1995), Statement on Co-operative Identity, Manchester, UK.

5. Gulan, B. (2013), Crna slika sela u Srbiji (Black Picture of the Village in Serbia), Agrobiznis, 17.04.2013, www.agrobiznis.biz.

6. Hofstede, G. (2001): Culture's Consequences: Comparing Values, Behaviors, Institutions and Organizations Across Nations, Thousand Oaks CA: Sage Publications

7. Iliopoulos, C. (2013): Public Policy Support For Agricultural Cooperatives: An Organizational Economics Approach, Annals of Public and Cooperative Economics, John Wiley and Sons, Oxford, Vol. 84, No. 3, pp. 241-252 
8. Janićijević, N. (2008): Organizaciono ponašanje (Organizational Behavior), Data Status, Beograd

9. Mijatović, B., Paunović, M., Kovačević, V. (2012): Social Entrepreneurship in Serbia, Center for Liberal Democratic Studies, Belgrade

10. Nacrt Zakona o zadrugama (Draft Law on Cooperatives) (2015): available at: http:// www.privreda.gov.rs/wp-content/uploads/2015/09/Nacrt-Zakona-O-Zadrugama1.pdf (accessed: 4.10.2015)

11. Narodna Skupština Republike Srbije (2006): Ustav Republike Srbije, Službeni. glasnik RS, br. 98/2006 (National Assembley of the Republic of Serbia, 2006, Constitution of the Republic of Serbia, RS Official Gazzette, No. 98/2006)

12. Osnovni zakon o zemljoradničkim zadrugama (1949): Službeni list FNRJ, 6. jun (Basic Law on Farm Cooperatives, Official Gazette of the Federal Republic of Yugoslavia, June 6, 1949F)

13. Ševarlić, M. (2012): Strategy for the Development of Agricultural Cooperatives in the Republic of Serbia, Serbian Association of Agricultural Economists (DAES), Beograd

14. Social Inclusion and Poverty Reduction Unit and Republic Statistical Office (2012): Monitoring Social Inclusion in Serbia, Republic of Serbia, Belgrade

15. Šunderić, Z. (2008): From Poverty Reduction to Social Inclusion: Improved Delivery of Government Policy, Social Inclusion and Poverty Reduction Unit, Republic of Serbia, Belgrade

16. USAID Agribusiness project (2008): Vegetable Value Chain Assesment, http://www. docstoc.com/docs/40456537/VEGETABLE-VALUE-CHAIN-ASSESSMENT accessed on $22 / 05 / 2014$

17. Valentinov, V. (2007): Why are cooperatives important in agriculture? An organizational economics perspective, Journal of Institutional Economics, Volume 3, No. 01, pp 55 $-69$

18. Zadružni savez Srbije (2012): Vodič kroz zemljoradničko zadrugarstvo (Guide through Farmers' Cooperatives), Beograd

19. Zakić, Z., Stojanović, Ž. (2009): Ekonomika agrara (Economics of Agriculture), CID, Ekonomski fakultet Univerziteta u Beogradu, Belgrade

20. Zakon o zadrugama (1990): Službeni glasnik SRJ, broj 57/89,67/93, 46/95, 101/05 (Law on cooperatives, , Official Gazette of the Federal Republic of Yugoslavia, No. $57 / 89,67 / 93,46 / 95$ and 101/05)

21. Zakon o udruženom radu (1976): Službeni glasnik broj 53/764, 3. decembar, (Law on Associated Labour, Official Gazette of the Socialistic Federal Republic of Yugoslavia, No $53 / 764,3^{\text {rd }}$ of December)

22. Zakon o zadrugama (1996): Službeni list SRJ, broj 41/96, 12/98 (Law on cooperatives, Official Gazette of the Federal Republic of Yugoslavia, No. 41/96 and 12/98) 


\title{
KRITIČKI OSVRT NA PRAVNI OKVIR KAO FAKTOR RAZVOJA ZADRUGARSTVA - PRIMER SRBIJE
}

\author{
Goran Petković5 ${ }^{5}$ Biljana Chroneos Krasavac 6 , Vlado Kovačević ${ }^{7}$
}

\begin{abstract}
Apstrakt
Savremeno zadrugarstvo mora počivati na originalnim zadružnim principima koji su potvrđeni i osavremenjeni od strane Kongresa međunarodnog zadružnog saveza koji je održan u Mančesteru 1995. godine. Razvoj pravnog okvira kojim se reguliše zadružni sektor u Srbiji ima duboko istorijsko nasleđe. Danas je problematika zadrugarstva u Srbiji regulisana federalnim Zakonom o zadrugama iz 1996. godine. Radom se analizira u kojoj meri pravni okvir može biti podsticaj i/ili prepreka uspešnom funkcionisanju zadruga u Srbiji kao i koja vrsta rezultata se može očekivati uvođenjem modernizovanog i unapređenog pravnog okvira. Intervju sa ključnim akterima u sektoru zadrugarstva je istraživački metod koji je korišćen u radu. Ostali istraživački metodi uključuju istorijski metod, metod komparativne analize kao i metod studije slučaja. Rad se sastoji iz četiri dela: istorijska i pravna pozadina razvoja zadruga u Srbiji, pravni okvir, studija uspešnog slučaja, okvir i smernice budućeg razvoja. Radom se takođe analizira $i$ socijalni aspekt zadrugarstva, kao i uloga zadruga u procesu socijalne inkluzije.
\end{abstract}

Ključne reči: zadruge, pravni okvir, vlasništvo, poljoprivredno gazdinstvo, individualni proizvođači.

5 Redovni profesor, dr Goran Petković, Univerzitet u Beogradu, Ekonomski fakultet, Ulica Kamenička br. 6, Beograd, Srbija, Telefon: +381 113021 130, E-mail: pego@eunet.rs

6 Docent, dr Biljana Chroneos Krasavac, Univerzitet u Beogradu, Ekonomski fakultet u Beogradu, Ulica Kamenička br. 6, Telefon: +381 113021 186, E-mail: biljanak@ekof.bg.ac.rs

7 Naučni saradnik, Vlado Kovačević, savetnik ministra, Ministarstvo poljoprivrede i zaštite životne sredine, Ulica Nemanjina br. 22-26, Beograd, Srbija, Telefon: +381 646581519 , E-mail: vlado.kovacevic@minpolj.gov.rs 